\title{
The water pools of the Agrakhan Bay area in the Terek River delta and scientifically based measures for their conservation
}

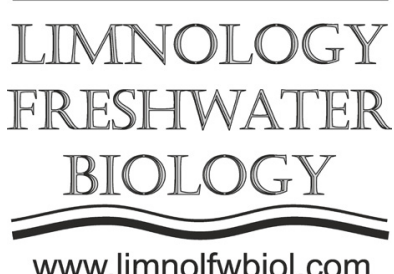

www.limnolfwbiol.com

\author{
Samokhin M.A. ${ }^{1 *}$, Magritskiy D.V. ${ }^{1}$, Sokolov D.I. ${ }^{1}$, Erina O. ${ }^{1}$, Goncharov A.V. ${ }^{1}$, \\ Surkov V.V. ${ }^{1}$, Semenova A.A. ${ }^{1}$, Zavadskiy A.N. ${ }^{1}$, Vorontsov A.A. ${ }^{2}$, Tereshina M.A. ${ }^{1}$ \\ ${ }^{1}$ Lomonosov Moscow State University, Leninskiye Gory, GSP-1, Moscow, 119991, Russia \\ ${ }^{2}$ All-Russian Research Institute of Hydrometeorological Information - World Data Center, Koroleva St., 6, Obninsk, 249020, Russia
}

\begin{abstract}
We have described the current hydrological state of the Agrakhan Bay, studied its features and defined trends, factors and parameters of hydrologic-morphological evolution of the Bay, mainly in the XX and early XXI centuries, and proposed measures for its restoration. The study was based on field measurements and long-term networked hydrological observations, comparative analysis of multitemporal cartographic material and satellite images, and laboratory analysis of water samples. Agrakhan Bay is a unique hydrographic and ecologically valuable object in the south-eastern part of the Terek delta, which 100 years ago had the features of a typical sea gulf and an area of $340 \mathrm{~km}^{2}$, was one of the main habitats for sturgeon spawning and fishery. Now it is divided into two different parts. Water areas and watered reed cover only $258 \mathrm{~km}^{2}$. Their area continues to decrease, which generates negative environmental and socio-economic consequences. The fishing value of the bay has been lost.
\end{abstract}

Keywords: Terek, delta, Caspian Sea, hydrological conditions, morphological structure

\section{Introduction}

The Agrakhan Bay is a unique body of water located at the south-eastern part of the Terek River delta that serves as a habitat for many rare and protected animal, fish, bird and plant species. It also acts as a natural barrier restricting the spread of the Agrakhan Peninsula sands into the delta, and maintains the groundwater levels, limiting the salinization of surrounding land. In early $20^{\text {st }}$ century, it was a typical marine inlet of the Caspian Sea with surface area of approximately $340 \mathrm{~km}^{2}$. At the present time, the Kargalinsky Proryv (a branch of the Terek River delta) divides the bay into two separate and unequal parts with individual hydrology, landscape features, biota and patterns of anthropogenic impact. It is, however, still listed as a marine bay in the Russian water registry, and is labeled on maps the same way.

Currently there are multiple threats to the very existence of the remaining part of this unique hydrological system, including decreasing water level of the Caspian Sea, siltation, macrophyte overgrowth, and pollution. The task of stopping the degradation of the Agrakhan Bay is hampered by nearly complete absence of up-to-date data on its hydrology, poor understanding of the factors causing the deterioration, and absence of examples of successful restoration of such naturals systems in Russian water management practice.

\section{Materials and methods}

As a basis for this study we used the data of 7 expeditions that were carried out in 2018-2019 within the framework of a pioneering research project proposed by the Western Caspian water administration office. Surface and groundwater level monitoring was established on the lakes and waterways of the Agrakhan Bay; 4 rounds of water discharge measurements, 6 campaigns of water chemistry sampling, hundreds of hydrophysical measurements, bottom sediment sampling and hydrobiological studies were performed, along with surface elevation and depth measurements at over 2000 terrestrial and over 100,000 on-water points.

Multiple historical and modern maps and satellite images were used, as well as the long-term observation records from the gauging stations in the Terek delta, data on the dynamics of the Caspian Sea level, and results of previous field studies on the bay and surrounding area (Belyaev, 1963; Baydin et al., 1971; Kaspiyskoye more..., 1993; Kravtsova and Ilyukhina, 2002; Mikhaylov et al., 2004; 2013; Gorelits and Zemlyanov, 2011; Alekseevskiy et al., 2014).

\section{Results and Discussion}

The southern sector of the bay, referred to as the 
South Agrakhan, is a closed water pool with artificially maintained water balance. It is isolated from both the Caspian Sea and the North Agrakhan (with about $2 \mathrm{~m}$ difference in surface elevation) and has limited water exchange with the Kargalinsky Proryv. It is almost completely overgrown by common reed in its northern, north-western and southern parts; large parts of the open area are covered in submerged aquatic vegetation. The South Agrakhan is relatively stable, but experiences ongoing siltation and macrophyte overgrowth.

The northern sector is a group of small lakes and wetland areas with an increasing proportion of drying reed beds in its southern part and 2 types of waterbodies: shallow flat lakes (some of them seasonal) in the south, and a large water mass directly connected to Northern Caspian Sea at the north. Periodically flooded reed beds are widely spread, but submerged vegetation is less common due to high water turbidity. The main concern here is the loss of water caused by the declining level of the Caspian Sea and decreasing river and canal inflow.

The water of the Agrakhan Bay is rated as "polluted". The average annual siltation rate is estimated as $5-8 \mathrm{~mm} / \mathrm{yr}$. The greatest bottom sediment pollution is noted at the southern and northern parts of the South Agrakhan, in the Kubyakinsky branch of the Terek delta and in some of the lakes in the northern sector. The bottom sediments of the southern part of the bay are 2-3 times less salinized than those of the northern sector.

We have also developed a detailed GIS for the Agrakhan Bay territory. It can be considered the first ever database of cartographic data covering the historical development of the bay boundaries, its landscapes, bed topography, coverage of aquatic vegetation and bottom sediment mapping; hypsographic curves were also calculated.

\section{Conclusions}

The degradation of morphological and hydrological structure of the Agrakhan Bay is undeniable and is speeding up under an array of factors: 1) rapid and significant shift in the Caspian Sea level, 2) siltation of the remaining water pools with the Terek
River sediment, 3) extensive water use in the Terek delta, and 4) nutrient pollution of the water.

A possible solution for preserving the southern part of the bay is to take measures to reduce pollution levels of the canals flowing into the bay, increase river inflow, control the spreading of aquatic flora, and dredging. For the northern part, it can be recommended to construct levees around the wetland and lake areas, provide an inflow of less turbid water from the South Agrakhan, increase river inflow, dredge the Kubyakinsky branch and some of the lakes, clearing the reed beds, introducing a cattle grazing ban and more.

\section{References}

Alekseevskiy N.I., Aligadzhiyev M.M., Aliyev Sh.G. et al. 2014. Ozero Yuzhnyy Agrakhan: problemy ekologicheskoy reabilitatsii [Lake South Agrakhan: challenges of ecological rehabilitation]. Makhachkala: Epokha. (in Russian)

Baydin S.S., Skriptunov N.A., Shteynman B.S. et al. 1971. Gidrologiya ust'yevykh oblastey Tereka i Sulaka [Hydrology of the Terek and Sulak River mouths]. Moscow: Gidrometeoizdat. (in Russian)

Belyaev I.P. 1963. Gidrologiya del'ty Tereka [Hydrology of the Terek River delta]. Moscow: Gidrometeoizdat. (in Russian)

Gorelits O.V., Zemlyanov I.V. 2011. Stages of the Terek River delta development in modern conditions. Trudy GOIN [Proceedings of the State Oceanorgaphic Institute] 213: 369-380. (in Russian)

Kaspiyskoye more. Gidrologiya ust'yev rek Tereka i Sulaka [Caspian Sea. Hydrology of the Terek and Sulak river mouths]. 1993. Moscow: Nauka. (in Russian)

Kravtsova V.I., Ilyukhina Yu.A. 2002. Dynamics of the eastern part of the Terek River mouth during the rise of the Caspian Sea: mapping based on remote sensing data. Vodnyye Resursy [Water Resourses] 29(1): 49-61. (in Russian)

Mikhaylov V.N., Kravtsova V.I., Magritskiy D.V. et al. 2004. Deltas of the Caspian rivers and their response to the changing sea level. Vestnik Kaspiya [The Caspian bulletin] 6(50): 60-104. (in Russian)

Mikhaylov V.N., Korotayev V.N., Rychagov G.I. et al. 2013. Ust'ya rek Kaspiyskogo regiona: istoriya formirovaniya, sovremennyye gidrologo-morfologicheskiye protsessy i opasnyye gidrologicheskiye yavleniya [River mouths of the Caspian region: history of development, current hydrological and morphological processes and hazard events]. Moscow: GEOS. (in Russian) 